3. Сарчук Е.В., Лебедева А.М., Узбекова Л.Д. «Шумовое загрязнение как патогенный фактор для здоровья человека» «StudNet»№4/20 стр 332-340

4. Чумачева Н.М., Гурин М.А., Рубель Е.В., Шум и его влияние на организм человека. Технические науки.2016г №10(58) стр21-25

5. Васюткина Д.И., Производственный шум и его влияние на организм человека. Вестник Белгородского государственного технологического университета им. В.Г. Шухова» 2013-№1

\title{
Каминская Л.А., Агаева Л.С., Муратова А.А. \\ Изучение мнения молодых лиц женского пола об их здоровье на фоне ряда социальных и бытовых факторов жизни
}

ФГБОУ ВО Уральский государственньй медицинский университет (Россия, Екатеринбург)

doi: $10.18411 / \mathrm{j}-06-2021-15$

\section{Аннотация}

В статье представлены результаты мнения 72 молодых девушек в возрасте 16 24 года, полученные в результате анонимного анкетирования в социальных сетях, о состоянии их здоровья при воздействии социальных и бытовых факторов. По итогам ответов «да», «нет», «не знаю» на вопрос «Считаете себя здоровой?» составлены три группы сравнения. Ответы на вопросы о качестве сна, хорошем настроении, головной боли, возможности отдыха, комфортного состояния на работе (учебе), посещении зубного врача, контроле состояния здоровья объективно отражают различие мнения о состоянии здоровья в трех группах и выделяют ведущие факторы. Вопросы анкетирования могут быть использованы для аналогичных обследований.

Ключевые слова: здоровье, девушки, анонимное анкетирование, социальные сети, социальные, бытовые факторы.

\section{Abstract}

The article presents the results of the opinion of 72 young girls aged 16-24 years, obtained as a result of anonymous questioning in social networks, about their state of health under the influence of social and household factors. As a result of the answers "yes", "no", "I do not know" to the question "Do you consider yourself healthy?" made up three comparison groups. Answers to questions about the quality of sleep, good mood, headache, the possibility of rest, a comfortable state at work (study), visiting the dentist, monitoring the health status objectively reflect the difference in opinions about the health status in the three groups and highlight the leading factors. The questionnaire questions can be used for similar surveys.

Keywords: health, girls, anonymous survey, social networks, social, household factors.

Молодежь - особая социально-демографическая группа, которая отличается от взрослых биологическими возрастными особенностями и положением в социальной структуре общества. Диапазон возраста оставляет от 14-15 лет до 29-30 лет. От молодежи зависит экономическое и демографическое будущее любого государства. Поэтому на первый план выходят факторы, определяющие их качество жизни, в том числе формирующие образ жизни и состояние здоровья [2]. Многочисленными исследованиями показано, что здоровье примерно на 50 \% и более определяют образ жизни и условия жизнедеятельности, на $20 \%$ - состояние окружающей среды, на $20 \%$ - генетические факторы и на $10 \%$ - уровень развития и деятельность здравоохранения [1]. В большом обследовании молодежи в возрасте 14-30 лет 4 \% лиц женского пола оценили свое здоровье как «отличное», как «хорошее» $76 \%$ и как «удовлетворительное» $18 \%$. Половина девушек ответили, что у них достаточно отдыха, тогда как другая половина наоборот не удовлетворены своим отдыхом и 
считают, что им не мешало бы иметь больше свободного времени. Удовлетворены своим сном 66\%, тогда как $34 \%$ считают, что спят мало, либо имеют беспокойный сон. Получают достаточно много положительных эмоций $64 \%$, и это хорошим образом сказываются на их здоровье. Отсутствие культуры питания и переедание являются одной из основных причин, влияющих на состояние здоровья, считают $28 \%$ опрошенных, и 40 \% отмечают, что чрезмерное увлечение компьютерными играми, Интернет-зависимость пагубным образом сказываются на здоровье современной молодежи [3].

Цель исследования Анализ результатов анкетирования молодежи женского пола для изучения влияния на здоровье социальных и бытовых факторов жизни

\section{Материалы и методы исследования}

Проведен анонимный опрос через социальные сети среди молодежи женского пола в возрасте 16 -34 года, в стандартной программе платформы Google Forms. Критерии включения: указанный возраст и наличие полного комплекта ответов. Обсуждаются 72 ответа. Содержание вопросов и характер ответов представлен в части статьи «Результаты и обсуждение». Для самооценки вопросов №№ 1 - 9 были предложены варианты ответов: «всегда», «иногда, «никогда». Для вопроса № 10 предусмотрены варианты ответа «да», «нет», «не знаю». Проведена статистическая обработка результатов с использованием программы STATISTICA - 10.

\section{Обсуждение результатов}

Средний возраст девушек участвующих в опросе, $(18,7 \pm 0,87)$ лет, интервал (16- 24) года. При составлении анкеты мы полагали в дальнейшем для проведения анализа результатов анкетирования, взять за основу для формирования групп индексы массы тела (ИМТ), поскольку проблема высокого ИМТ в настоящее время является актуальной среди молодежи и вызывает тревогу медиков. Антропометрические данные по сведениям, полученным от анкетированных, представляют следующие данные: рост $(167,7 \pm 7,6)$ см, интервал(158 - 182) см, масса тела $(60,4 \pm 9,8)$ кг, интервал (43-72) кг. Расчет ИМТ показал результат $(21,1 \pm 2,6)$, что находится в пределах принятой нормы ИМТ $=25$. На рис 1 представлена диаграмма распределения значения ИМТ среди опрошенных.

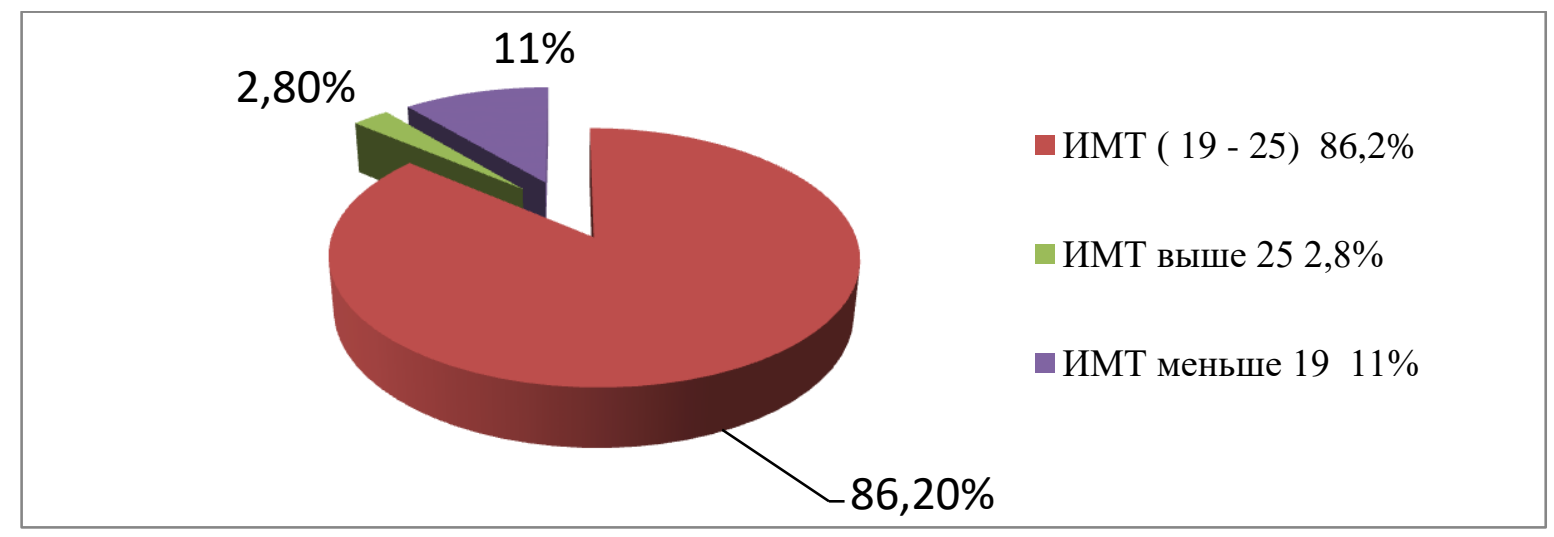

Рис.1. Распределения значения ИМТ среди опрошенных

Нормальным ИМТ обладают 86,2\% опрошенных, ниже нормы -11\% и выше нормы 2,8\% [4].

На основании полученных ответов были составлены три группы, за основу классификации был использован ответ на вопрос «Считаете себя здоровой?». Участники №1 группы ответили на этот вопрос утвердительно - «Да», участники №2 группы ответили отрицательно «Нет», участники №3 группы - «Не знаю». В №1 группе 34 девушки, возраст $(18,7 \pm 0,9)$ лет, в №2 группе 17 девушек, возраст $(19,0$ $\pm 1,0)$ лет; в №3 группе -21 участница, возраст $(19,4 \pm 1,1) ;$ ИМТ группы №1 $(20,5 \pm 1,7)$, 
группы№ $2(22,4 \pm 3,4)$, группы №3 $(21,9 \pm 3,3)$. Статистически достоверных отличий в отношении названных показателей между группами нет. На вопрос: «Считаете себя здоровыми?» ответили 47\% участников - да (группа №1), 24\% - нет (группа №2), 29\% не знаю (группа №3) (рис 2). Недавно проведенное нами обследование девочек подростков 12-14 лет показало, что три четверти опрошенных подростков считают себя здоровыми, но у 92\% иногда болит голова, 63\% плачут без причины [5]. В таблице 1 представлены результаты ответов опрошенных в социальной сети девушек трех групп. При сравнении ответов девушек №1 группы и № 2 группы можно выделить следующие сходства и отличия. В обеих группах равное количество участников имеют нормальный сон (высыпаются $18 \%$ ), и есть время для отдыха (практически тоже равное, соответственно 27\% и $30 \%$ ).

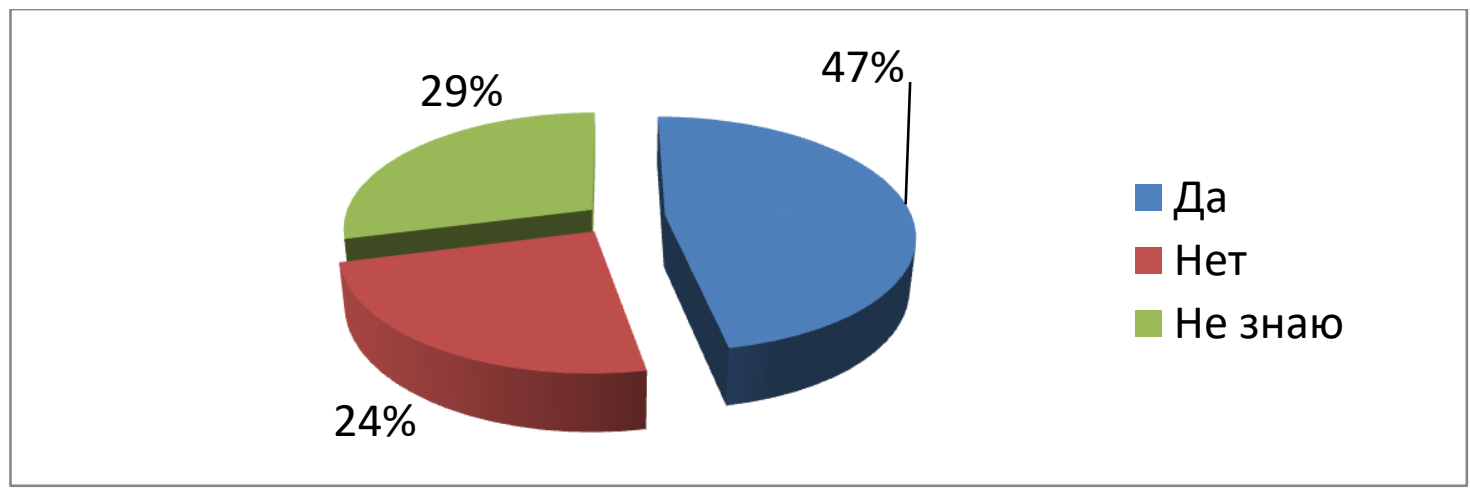

Рис 2. Распределение ответов на вопрос ««Считаете себя здоровыми?»

В остальных ответах возникают серьезные отличия, показатели №1 группы являются в отношении других ответов наиболее благополучными (табл. 1).

Таблицча 1

Результаты ответов опрошенных девушек в группах №1, №2, №3 Примечание: ответы в соответствии с номером группь даны в каждом столбче через косую черту (№1/№2/№3).

\begin{tabular}{|l|l|c|c|c|}
\hline \multirow{2}{*}{ Вопросы } & \multicolumn{1}{|c|}{ Варианты ответов (\% от общего числа ответов) } \\
\cline { 2 - 4 } & всегда & иногда & никогда \\
\hline & Вы высыпаетесь? & $18 / 18 / 0$ & $68 / 64 / 100$ & $14 / 18 / 0$ \\
\hline & У Вас хорошее настроение? & $42 / 12 / 20$ & $53 / 58 / 80$ & $5 / 30 / 0$ \\
\hline & Вы нервничаете без заметной причины? & $28 / 47 / 40$ & $50 / 30 / 60$ & $22 / 23 / 0$ \\
\hline У Вас болит голова? & $0 / 30 / 0$ & $85 / 53 / 70$ & $15 / 37 / 30$ \\
\hline & У Вас есть время для отдыха? & $27 / 30 / 13$ & $70 / 47 / 85$ & $3 / 33 / 0$ \\
\hline & Ваш аппетит хороший? & $8 / 16 / 0$ & $70 / 78 / 70$ & $22 / 6 / 22$ \\
\hline \multirow{2}{*}{$\begin{array}{l}\text { Вы ощущаете себя комфортно на работе, в } \\
\text { учебе? }\end{array}$} & комфортно & напряженно & не знаю \\
\cline { 2 - 4 } & $80 / 41 / 39$ & $12 / 41 / 22$ & $8 / 18 / 39$ \\
\hline & часто & редко & никогда \\
\hline & Вы контролируете свое состояние? & $62 / 24 / 25$ & $38 / 64 / 75$ & $0 / 12 / 0$ \\
\hline & Вы посещаете зубного врача? & $60 / 38 / 30$ & $40 / 53 / 70$ & $0 / 9 / 0$ \\
\hline
\end{tabular}

Респонденты №2 группы значительно чаще нервничают без заметной причины (47\% против 28\% в №1 группе); редко хорошее настроение (12\%); часто контролируют свое состояние всего $24 \%$; на работе (учебе) ощущают себя комфортно только $41 \%$ против $80 \%$ в №1 группе; часто посещают зубного врача только $38 \%$ опрошенных. Именно эти показатели можно считать ведущими в формировании ответа «Нет» на вопрос «Считаете себя здоровой?». Необходимо было провести анализ ответов девушек №3 группы, чтобы найти ответ, что послужило причиной ответа «Не знаю» на вопрос «Считаете ли себя здоровой». Высыпаются иногда 100\% опрошенных, это больше чем в группах №№1,2. Хорошее настроение меньше, чем в группе № 1 и больше, чем в группе № 2; нервничают без причины всегда больше, чем 
в группе №1 и меньше, чем в группе №2. В равной мере с группой №2 ощущают себя комфортно на работе и с такой же невысокой частотой контролируют свое состояние.

\section{Выводы}

Проведенное нами анонимное анкетирование в социальных сетях выявило, что те социальные и бытовые факторы жизни, которые представлены в составе вопросов анкеты, оказывают влияние на мнение опрошенных молодых (возраст 16- 24 года) девушек о состоянии своего здоровья: о качестве сна, хорошем настроении, головной боли, возможности отдыха, комфортного состояния на работе (учебе), посещении зубного врача, контроле состояния здоровья - эти вопросы объективно отражают различие мнения о состоянии здоровья в трех группах и выделяют ведущие факторы. Вопросы анкетирования могут быть использованы для аналогичных обследований.

\section{***}

1. Зимина Л.А., Боева А.В. Характеристика некоторых факторов, влияющих на здоровье молодежи // Международный журнал прикладных и фундаментальных исследований. - 2016. - № 1-3. - С. 347 351. URL: https://applied-research.ru/ru/article/view?id=8508

2. Еремина Э.В. Формирование здорового образа жизни среди молодежи// Материалы IX Международной студенческой научной конференции «Студенческий научный форум» URL: https://scienceforum.ru/2017/article/2017035304">https://scienceforum. ru/2017/article/2017035304</a>:

3. Иванова Т.Н. Сравнительный анализ влияния факторов риска на здоровье молодежи: гендерные различия (социологический аспект)// Балтийский гуманитарный журнал. -2019.-т.8.- №2 (27).- С. 50-54.

4. О чем говорит индекс массы тела? ИMT - зеркало здоровья человека. URL: https://meduniver.com/Medical/profilaktika/indeks_massi_tela.html

5. Хаматханова А.Н., Каминская Л.А. Самооценка девочками - подростками здоровья и влияющих на него факторов жизненного пространства// Актуальные вопросы современной медицинской науки и здравоохранения: Материалы VI Международной научно-практической конференции молодых учёных и студентов, посвященной году науки и технологий. [Электронный ресурс], Екатеринбург, 8-9 апреля 2021 г. - Екатеринбург: Издво УГМУ, 2021. - Том 1. - С.1485-1488.

\section{Карсанова А.Л.}

\section{Современные представления о роли витамина D}

Северо-Осетинский государственный университет им. К.Л.Хетагурова (Россия, Владикавказ)

doi: $10.18411 / \mathrm{j}-06-2021-16$

\section{Аннотация}

Обзор посвящен обобщению современной информации о роли витамина D в регуляции метаболизма растущего организма. Ранее витамин D ассоциировался только с фосфорно-кальциевым обменом, в настоящее время описано его влияние на многие ткани и выявлено, что витамин D взаимодействует со специфическими рецепторами, расположенными в тканях-мишенях. Определено его влияние на поджелудочную железу, регуляцию иммунной, сердечно-сосудистой, костной систем, показана прямая зависимость развития инфекционных, аллергических, аутоиммунных, сердечнососудистых заболеваний от уровня витамина D.

Ключевые слова: витамин D; метаболизм; концентрации 25(OH)D; Dвитаминный статус населения; полиморфизм генов; мутации в гене рецептора витамина D.

\section{Abstract}

Review of the literature is devoted to the discussion of the influence of vitamin D on all the types of metabolism. The aim was to compile information on role of vitamin D. Previously, vitamin D was associated with the only calcium \& phosphorus metabolism, now there is described the study concerning the effect of vitamin D in many tissues of the human 